ARTICLE

Received 26 Sep 2012 | Accepted 19 Mar 2013 | Published 23 Apr 2013

DOI: $10.1038 /$ ncomms 2770

\title{
Biological carbon precursor to diagenetic siderite with spherical structures in iron formations
}

Inga Köhler ${ }^{1}$, Kurt O. Konhauser ${ }^{2}$, Dominic Papineau ${ }^{3,4}$, Andrey Bekker ${ }^{5}$ \& Andreas Kappler ${ }^{1}$

During deposition of Precambrian iron formation, the combined sedimentation of ferrihydrite and phytoplankton biomass should have facilitated Fe(III) reduction during diagenesis. However, the only evidence for this reaction in iron formations is the iron and carbon isotope values preserved in the authigenic ferrous iron-containing minerals. Here we show experimentally that spheroidal siderite, which is preserved in many iron formation and could have been precursor to rhombohedral or massive siderite, forms by reacting ferrihydrite with glucose (a proxy for microbial biomass) at pressure and temperature conditions typical of diagenesis $\left(170^{\circ} \mathrm{C}\right.$ and $1.2 \mathrm{kbar}$ ). Depending on the abundance of siderite, we found that it is also possible to draw conclusions about the $\mathrm{Fe}(\mathrm{III}): \mathrm{C}$ ratio of the initial ferrihydrite-biomass sediment. Our results suggest that spherical to rhombohedral siderite structures in deepwater, Fe-oxide iron formation can be used as a biosignature for photoferrotrophy, whereas massive siderite reflects high cyanobacterial biomass loading in highly productive shallowwaters.

\footnotetext{
${ }^{1}$ Geomicrobiology Group, Center for Applied Geoscience, University of Tuebingen, Sigwartstrasse 10, 72076 Tuebingen, Germany. ${ }^{2}$ Department of Earth and Atmospheric Sciences, University of Alberta, Edmonton, Alberta, Canada T6G 2E3. ${ }^{3}$ Department of Earth and Environmental Sciences, Boston College, 140 Commonwealth Avenue, Devlin Hall 213 Chestnut Hill, Massachussets 02467, USA. ${ }^{4}$ Geophysical Laboratory, Carnegie Institution of Washington, Washington DC 20015, USA. ${ }^{5}$ Department of Geological Sciences, University of Manitoba, Winnipeg, Manitoba, Canada R3T 2N2. Correspondence and requests for materials should be addressed to A.K. (email: andreas.kappler@uni-tuebingen.de).
} 
ron formations (IFs) are marine chemical sedimentary rocks that were precipitated throughout much of the Archaean and Paleoproterozoic before $\sim 1.85 \mathrm{Ga}$ (ref. 1). The precursor sediments, including amorphous ferric oxyhydroxides, such as ferrihydrite $\left(\mathrm{Fe}(\mathrm{OH})_{3}\right)$, required an oxidative mechanism to transform the dissolved hydrothermally-derived $\mathrm{Fe}(\mathrm{II})$ into solidphase $\mathrm{Fe}$ (III). It has been suggested that abiotic UV-light dependent oxidation of $\mathrm{Fe}$ (II) led to the precipitation of ferric hydroxide minerals ${ }^{2,3}$, but later experiments have shown that in seawater containing high concentrations of dissolved $\mathrm{Si}(\mathrm{OH})_{4}$ and $\mathrm{HCO}_{3}^{-}$the oxidation effects of either UVA or UVC are negligible compared to the precipitation of ferrous iron-silicates ${ }^{4}$. In contrast, two different roles for bacteria have been inferred in $\mathrm{Fe}(\mathrm{II})$ oxidation. The first is based on the production of $\mathrm{O}_{2}$ by oxygenic phototrophic cyanobacteria. Their Precambrian ancestors flourished when nutrients were available and their metabolically-produced $\mathrm{O}_{2}$ abiotically oxidized dissolved $\mathrm{Fe}$ (II) to $\mathrm{Fe}$ (III), followed by the hydrolysis and precipitation of ferrihydrite ${ }^{5}$. The second postulated role for bacteria in IF precipitation involves $\mathrm{Fe}(\mathrm{II})$-oxidizing microorganisms, including microaerophilic chemolithoautotrophic bacteria (for example, Gallionella ferruginea) that thrive today in suboxic waters and sediments ${ }^{6}$. Additionally, anoxygenic photoautotrophic Fe(II)oxidizing bacteria (photoferrotrophs) may have coupled the $\mathrm{C}$ and $\mathrm{Fe}$ cycles before the evolution of oxygenic photosynthesis ${ }^{7-9}$. A number of experimental studies have confirmed that various purple and green phototrophic bacteria can use $\mathrm{Fe}(\mathrm{II})$ as a reductant for $\mathrm{CO}_{2}$ fixation ${ }^{10}$. However, the relative influence of phototrophic bacteria on the origin of IF is not fully understood, because direct evidence for their involvement in $\mathrm{Fe}$ (II) oxidation has not been found and the fate of organic remains and ferrihydrite precipitates on the seafloor are still poorly characterized.

Given that the bulk of the ocean water column was anoxic throughout the Archaean and Paleoproterozoic, ferrihydrite represented a favourable electron acceptor for in situ oxidation of the cellular biomass remains associated with precursor IF sediments. Some Archaean magnetite-rich $\mathrm{IF}^{11-15}$ have highly negative $\delta^{56} \mathrm{Fe}$ values that are comparable to those measured from dissolved $\mathrm{Fe}$ (II) experimentally produced by cultures of dissimilatory $\mathrm{Fe}(\mathrm{III})$-reducing bacteria ${ }^{16}$, pointing to the antiquity of anaerobic dissimilatory Fe(III) reduction ${ }^{15,17}$. Alternatively, abiotic reactions between $\mathrm{Fe}(\mathrm{III})$ oxyhydroxides and organic carbon are expected to occur at temperatures above the threshold for microbial life during late-stage diagenesis and metamorphism ${ }^{18}$, which based on modern microbes is around $120^{\circ} \mathrm{C}$ (ref. 19). In either case, coupling the reduction of Fe(III) minerals to the oxidation of organic matter provides a simple explanation for the generally low content of organic carbon in IF $(<0.5 \%$ (refs 1,20$)$ ), as well as the light carbon and iron isotopic values of carbonate minerals ${ }^{1,15,21,22}$.

A number of petrographic studies have described the secondary origin of magnetite in $\mathrm{IF}^{23-26}$. Recently, Li et al. ${ }^{27}$ reported the detection of nanocrystals of apatite in association with magnetite from the $2.48 \mathrm{Ga}$ Dales Gorge IF in Western Australia; the latter had a crystal chemistry identical to modern biogenic magnetite. These considerations and features point to the original presence of biomass in IF precursor sediments, but also indicate that the organic carbon served as an electron donor during $\mathrm{Fe}$ (III) reduction. Beside magnetite and haematite, siderite is one of the most abundant Fe-bearing minerals in IF. The origin of siderite has been suggested to involve primary precipitation in the water column through the reaction of $\mathrm{Fe}^{2+}$ with bicarbonate from seawater as soon as the solubility product of siderite (controlled by the $\mathrm{Fe}^{2+}$ and carbonate/bicarbonate concentrations in the ocean water) is exceeded ${ }^{28,29}$. Alternatively, siderite can be formed during the diagenetic (biological or nonbiological), and subsequent metamorphic, oxidation of microbial biomass to $\mathrm{CO}_{2}$ /bicarbonate coupled to the reduction of $\mathrm{Fe}(\mathrm{III})$, followed by reactions of the product $\mathrm{Fe}^{2+}$ with the sediment pore-water bicarbonate ${ }^{30}$. Here, we show that spherical siderite in deep-water IF represents a biosignature for photoferrotrophy, whereas massive siderite reflects high cyanobacterial biomass in shallow-water.

\section{Results}

Experimental siderite formation. We experimentally tested whether the diagenetic transformation of biomass and primary $\mathrm{Fe}$ (III) oxyhydroxide minerals can form siderite, and whether that siderite is of similar size and morphology to those observed in IF. To this end, we incubated ferrihydrite (as a proxy for primary ferric oxyhydroxides) and glucose (as a proxy for microbial biomass) in gold capsules at $170^{\circ} \mathrm{C}$ and $1.2 \mathrm{kbar}$ (for a more detailed rationale explaining the choice of reactants and for methodological details see Supplementary Information). These chosen conditions simulate the degree of metamorphism in some of the major IF in South Africa and Western Australia that have been exposed to metamorphic grades below the prehnite-pumpellyite facies $^{31-33}$. After $24 \mathrm{~h}$ of incubation, haematite, magnetite and siderite were identified as reaction products by their optical properties (Fig. 1). Detailed microscopic analysis showed that the siderite was commonly present as spherical grains characterized by strong bireflectance and anisotropism (Fig. 2a,c). As no significant concentrations of $\mathrm{Mg}^{2+}$ and $\mathrm{Ca}^{2+}$ were present in our experiments, we deduce that the carbonate spheres are siderite. This has also been independently confirmed by Mössbauer spectroscopy and XRD (data not shown).

Siderite was present in close association with ferrihydrite and haematite, suggesting that the reduction of ferrihydrite or haematite coupled to the oxidation of biomass (for example, glucose) formed siderite, $\mathrm{Fe}^{2+}, \mathrm{OH}^{-}$, and potentially even $\mathrm{H}_{2}$, according to the following four reactions:

$$
\begin{aligned}
& 4 \mathrm{Fe}(\mathrm{OH})_{3}+\mathrm{CH}_{2} \mathrm{O} \rightarrow \mathrm{FeCO}_{3}+3 \mathrm{Fe}^{2+}+6 \mathrm{OH}^{-}+4 \mathrm{H}_{2} \mathrm{O} \\
& 2 \mathrm{Fe}_{2} \mathrm{O}_{3}+\mathrm{CH}_{2} \mathrm{O}+2 \mathrm{H}_{2} \mathrm{O} \rightarrow \mathrm{FeCO}_{3}+3 \mathrm{Fe}^{2+}+6 \mathrm{OH}^{-} \\
& 2 \mathrm{Fe}(\mathrm{OH})_{3}+2 \mathrm{CH}_{2} \mathrm{O} \rightarrow 2 \mathrm{FeCO}_{3}+2 \mathrm{H}_{2} \mathrm{O}+3 \mathrm{H}_{2} \\
& \mathrm{Fe}_{2} \mathrm{O}_{3}+2 \mathrm{CH}_{2} \mathrm{O}+\mathrm{H}_{2} \mathrm{O} \rightarrow 2 \mathrm{FeCO}_{3}+3 \mathrm{H}_{2}
\end{aligned}
$$

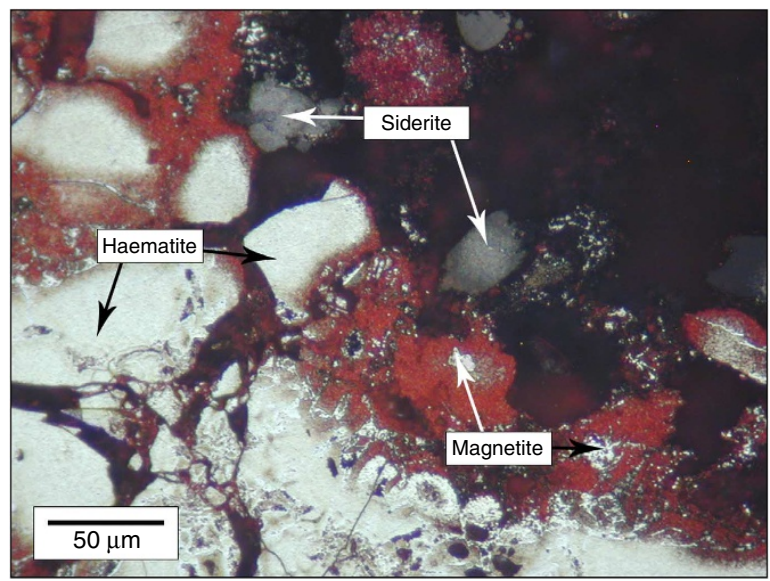

Figure 1 | Iron(II) and iron(III) minerals formed during pressuretemperature diagenesis. Reflected light microscopy image of a mixture of ferrihydrite and glucose after 1 day of pressure and temperature treatment at $1.2 \mathrm{kbar}$ and $170^{\circ} \mathrm{C}$, respectively. Haematite and magnetite have formed along with siderite. All three minerals can be found in close association with each other. Haematite forms large anhedral to subhedral crystals, which show small magnetite inclusions. Siderite is present as the typical grey sub-spherical structures. 

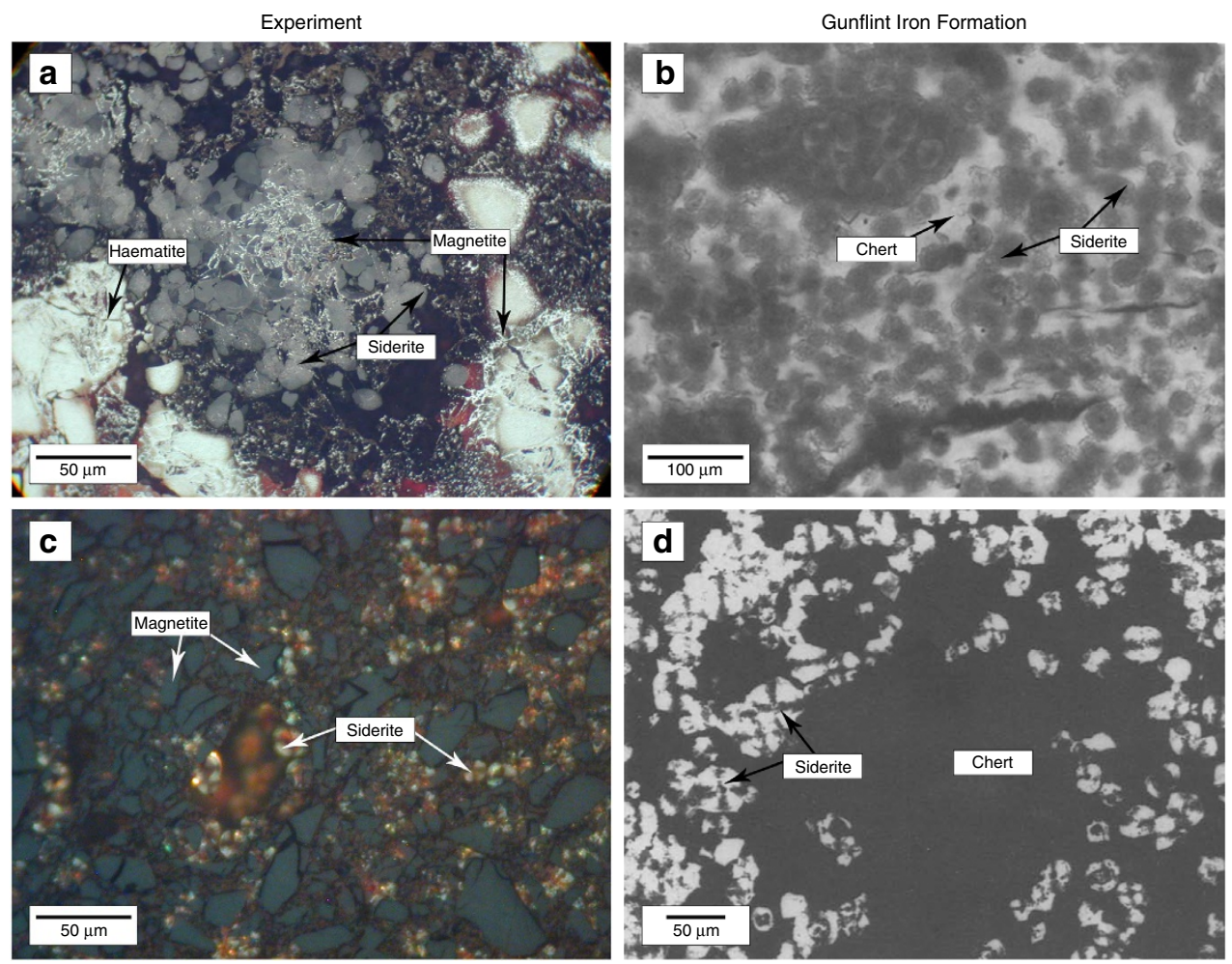

Figure 2 | Spherical siderite structures in diagenesis experiments and Precambrian IFs. Reflected light microscopy images of siderite spheres formed in diagenetic experiments from a mixture of ferrihydrite and glucose $(\mathbf{a}, \mathbf{c})$ compared with spherical siderite structures in IF (b,d). Ferrihydrite and glucose with an electron ratio of 0.6 was treated at $1.2 \mathrm{kbar}$ and $170{ }^{\circ} \mathrm{C}$ for 14 days. (a) Shows haematite, magnetite and spherical siderite formed in the diagenetic experiments in comparison to analogous spherical siderite structures in chert from the Gunflint IF near Kakabeka Falls, Ontario (b). (c) Ferrihydrite and glucose mixture (electron ratio of 2.4) under crossed polars. Magnetite is surrounded by siderite spheres that show distinct polarization crosses. These spheres are similar to siderite structures in the carbonate facies of the upper and lower Gunflint IF, Ontario ${ }^{34}$.

Comparison with siderite in IFs. Our experiments show that spherical siderite can form from the abiotic diagenetic oxidation of organic carbon coupled to a reduction of ferric iron during simulated late-stage diagenesis (Fig. 2a,c). Figure 2b,d show a comparison of diagenetically formed siderite spheres in our experiments with spherical siderite structures in the $1.88 \mathrm{Ga}$ Gunflint IF in Canada ${ }^{34-38}$. Siderite spheres with sizes of tens of microns can be observed in both the experimental and natural mineral assemblages where they appear as individual grains as well as in the form of aggregates when the grains coalesce. Similar structures of spherical siderite have also been described in IFs in the $2.48 \mathrm{Ga}$ Dales Gorge Member, Western Australia ${ }^{39,40}$ and $1.88 \mathrm{Ga}$ Riverton IF, Michigan, MI, USA ${ }^{41}$, although they are not as common in these successions as in the Gunflint IF. Such occurrences suggest that siderite spheres may have been a common feature of IFs before they were recrystallized during late diagenesis and metamorphism to rhombohedral/subhedral siderite grains or formed massive siderite beds. Consistent with this suggestion, it has been shown that in the Gunflint IF some siderite rhombohedra contain spheres in their cores and there is a clear progression from siderite spheres to siderite rhombohedra without any trace of spheres left ${ }^{37,42}$. This progression was also found in the Dales Gorge Member, where siderite spheres and rhombohedra occur in close proximity to each other (Fig. 3c). Note that some spheres already show signs of a recrystallization.

Influence of initial $\mathrm{Fe}(\mathrm{III}): \mathrm{C}$ ratios on siderite formation. In order to determine how varying levels of biomass might influence siderite formation and the internal morphology of spheres, we performed a second series of experiments using four times more glucose. The electron ratio, calculated with the total number of electrons potentially released from carbon in glucose divided by the number of electrons that can potentially be accepted by the $\mathrm{Fe}(\mathrm{III})$, was thus increased from 0.6 in the first experiments to 2.4 (see Supplementary Information). Experiments with an electron ratio of 0.6 simulate an excess of iron as would have occurred in a scenario in which the $\mathrm{Fe}^{2+}$ would be oxidized by anoxygenic photoferrotrophs (for example, Chlorobium sp.) or microaerophilic chemolithoautotrophs (for example, Gallionella sp.) (Fig. 3): preferential deposition of the dense Fe(III) minerals with low content of organic carbon has been demonstrated experimentally for photoferrotrophs ${ }^{43}$. In comparison, an electron ratio of 2.4 represents a system with a higher biomass input to the sediment as would be the case if there was either additional electron donors such as $\mathrm{H}_{2}$, or if a microbial metabolism, such as photosynthesis by cyanobacteria, occurred in the water column and was not directly tied to $\mathrm{Fe}$ (II) oxidation.

Our diagenesis experiments showed that siderite formed at both electron ratios and that it most commonly had a spherical shape (shown by black and white arrows in Fig. 2a,c) up to $20 \mu \mathrm{m}$ in diameter. Individual spheres sometimes coalesced to form aggregates. Associated with the siderite were haematite (in experiments with an electron ratio of 0.6 ) and magnetite (in both experiments). Magnetite was commonly found to be interspersed with haematite grains or as rims around haematite cores. In the experiment with an electron ratio of 2.4, magnetite grains were larger and often surrounded by siderite (Fig. 2c). The subspherical siderite crystals in the 2.4 electron ratio experiments showed distinct polarization crosses under crossed polars 


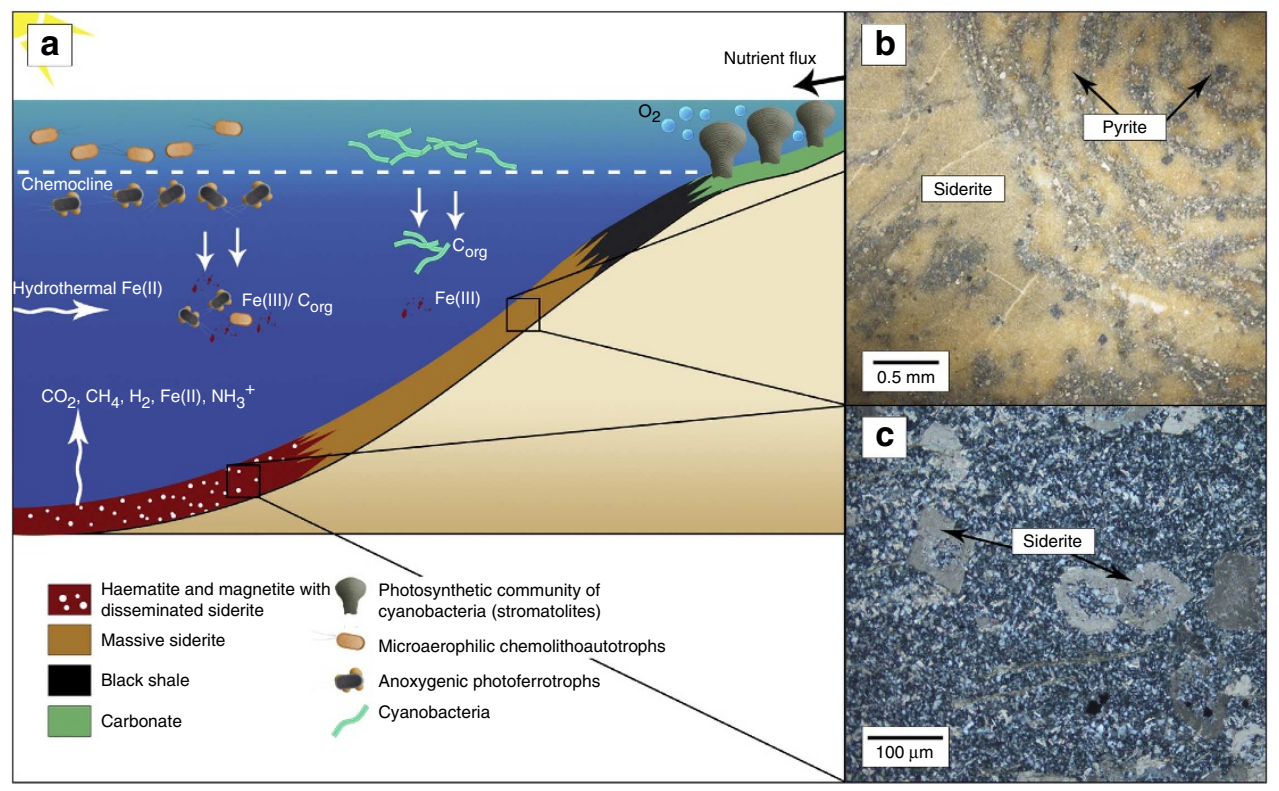

Figure 3 | Origin of massive siderite beds and spherical siderite structures in different depositional environments. Model summarizing the origin of shallow- and deep-water IF siderite (a). During periods of enhanced submarine volcanism, hydrothermal fluids leached Fe(II) from volcanics and exhaled it to the oceans. Fe(II) upwelling from the deep ocean resulted in the growth of microaerophilic chemolithoautotrophs and anoxygenic photoferrotrophs in the deep-water, photic zone above and below the chemocline, respectively. Due to low-cell densities in the active Fe(II)-oxidation zone and a much smaller $\mathrm{C}_{\text {org }}$ reduction potential in sediments with respect to the accumulated $\mathrm{Fe}(\mathrm{III})$, haematite and magnetite with disseminated spherical to rhombohedral siderite formed during diagenesis. By contrast, high riverine nutrient fluxes to shallow-water environments led to cyanobacterial blooms; this resulted in a C:Fe ratio of 1:4 or more, which is equal to or greater than the reduction ratio in sediments. This led to the formation of large quantities of siderite grains, which coalesced during diagenesis and metamorphism to form massive siderite beds. (b) Massive siderite beds formed in a shallow-water environment in association with stromatolites (with lamina highlighted by pyrite crystals) in the volcanically-dominated ca. 2.7 Ga Michipicoten greenstone belt, Wawa subprovince of the Superior province, Canada (reflected light image, Helen IF, MacLeod mine ${ }^{51}$ ). (c) In the deeper-water environments, sub-spherical to rhombohedral siderite structures formed during early diagenesis to low-grade metamorphism of IFs as shown in the photomicrograph under cross-nicols of the ca. 2.48 Ga Dales Gorge IF of Western Australia.

(Fig. 2c), suggesting either concentrical or radial crystal growth in siderite spheres ${ }^{34,44}$. Polarization crosses under crossed polars and radial crystal growth were only observed in capsules with a higher electron ratio, but were also observed in siderite spheres from the Gunflint IF (Fig. 2d; see also ref. 45) and from the Riverton IF of the Iron River district, Michigan ${ }^{41}$. The results thus suggest that these structures can be considered as an indicator for high organic carbon loading into the sediments. Consistent with this suggestion, siderite spheres in IFs often contain organic carbon inclusions ${ }^{42}$. To our knowledge, polarization crosses under crossed polars have not yet been described for siderite minerals formed by microbial reduction of Fe(III) minerals either in laboratory or in nature. Therefore, by comparison with previously described siderite spheres in IF, our experiments suggest that at least some siderite spheres were formed by abiotic diagenetic formation of siderite via reduction of $\mathrm{Fe}$ (III) oxyhydroxides with biomass.

Influence of silica on siderite formation. To test whether spherical siderite would also form in the presence of Si concentrations similar to those expected for the Archaean oceans, we carried out experiments with Si-coated ferrihydrite and glucose (Si:Fe ratio of 0.08 , electron ratio 0.6 , for details see Supplementary Information). We found that in the presence of Si, siderite also formed within 14 days and was visible both as individual spheres and as aggregates (Fig. 4).

\section{Discussion}

Although siderite can form via both abiotic and biotic mechanisms $s^{21,17,30}$, specific petrographic features of spherical siderite in
IF have been suggested to represent remnants of microbial cells based on their shape and internal structure ${ }^{35,36}$. Heaney and Veblen $^{34}$ argued for an indirect biological origin of nano-scale siderite spheres from the Gunflint IF as distinct cores of apatite were found within the siderite spheres. Based on a simple massbalance analysis, they inferred that it was the accumulation of 'thousands of individual organisms' that accounted for the relatively high amount of apatite inside of the spheres and for the spheres themselves. However, the described structures in the Gunflint IF have a size range between $24-115 \mu \mathrm{m}$ (Kazmierczak et $a l^{35}$ and Fig. 2b,d), and thus do not resemble the typical size of bacterial cells. In either case, several IF, including the Dales Gorge Member of Western Australia ${ }^{39,40}$, the Riverton IF in Michigan $^{41}$, and the Gunflint IF in Ontario ${ }^{38}$, have been reported to contain these distinctive structures. The presence of spherical siderite in IFs with different ages and from varied depositional settings, shallow and deep marine, suggests a common mechanism of their formation.

A key conclusion from our experiments is that the presence of siderite in IFs may allow a first-order estimate of the initial amount of sedimentary organic matter, and potentially even characterization of the ecosystem that grew in the photic zone during IF deposition. Using the Dales Gorge Member as an example, we calculated that based on measured $\mathrm{Fe}_{\text {TOTAL }}$ content, a plausible depositional rate of $1 \mathrm{~mm}$ per year ${ }^{46}$, and a post-precipitation reduction efficiency of $70 \%$ before burial ${ }^{47}$, the amount of $\mathrm{Fe}(\mathrm{III})$ precipitated could have been as high as $45.3 \mathrm{~mol}$ per year $\times \mathrm{m}^{2}$ (for details of calculation see Supplementary Information). Using an experimental rate of $\mathrm{Fe}(\mathrm{II})$ oxidation of $1.1 \times 10^{-11}$ mol per cell by chemolithoautotrophic bacteria $^{48}$, such as Gallionella ferruginea (one of the species 

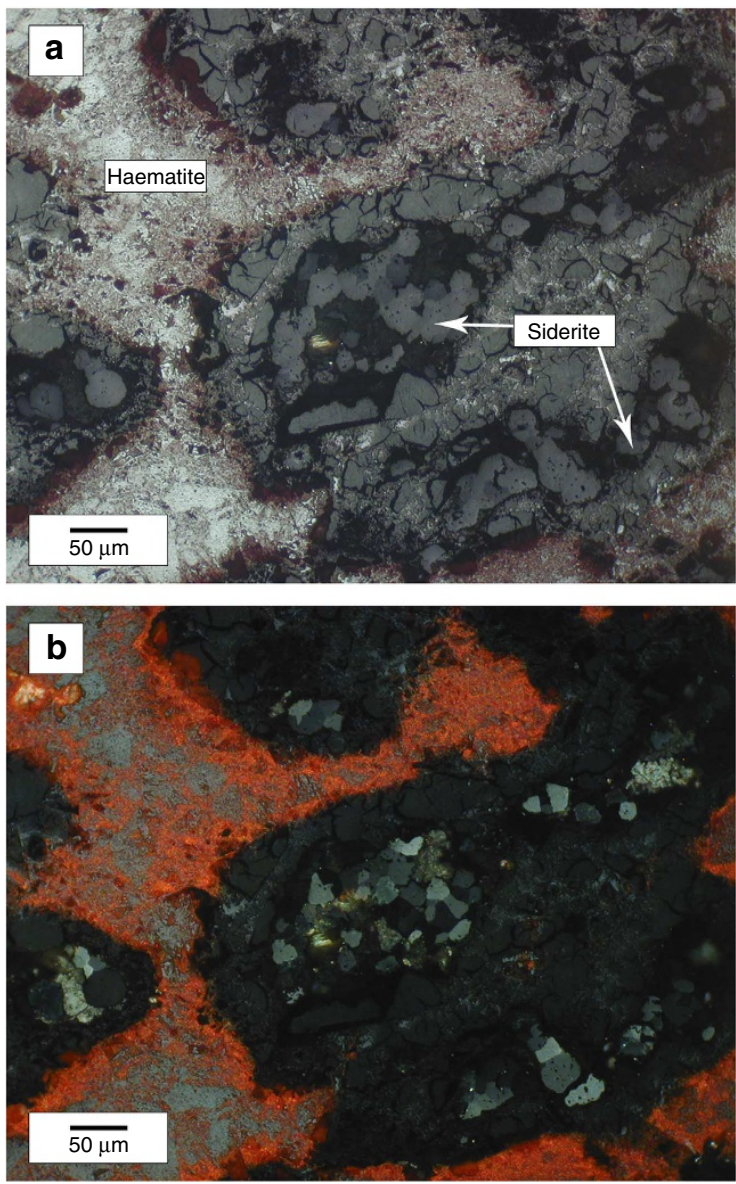

Figure 4 | Iron(II) and iron(III) minerals formed during pressuretemperature diagenesis in the presence of silica. Reflected light microscopy image (a) of minerals formed in diagenetic experiments with a mixture of silica-coated ferrihydrite and glucose (Si:Fe ratio of 0.08 , electron ratio 0.6 ). Siderite is visible as aggregates and as single globular structures. $\mathbf{b}$ shows an image of the same area under crossed polars.

believed to have played a prominent role in ferric iron precipitation in some $\mathrm{IF}^{49}$-see SOM), it is further possible to estimate the cell density of bacteria growing in the photic zone of early Precambrian seawater, as the rate of Fe(III) precipitation estimated above would necessitate population of chemolithotrophic bacteria on the order of $10^{5}$ cells per $\mathrm{ml}$ (for details of calculation see Supplementary Information) throughout the $\mathrm{Fe}(\mathrm{II})$ oxidation zone of the water column with a biologically active depth of $10 \mathrm{~m}$. Similar cell density would have existed if $\mathrm{Fe}(\mathrm{II})$ oxidation was primarily driven by photoferrotrophic bacteria.

Putting these numbers into context, we can envision two different scenarios that would have ultimately led to the different diagenetic/metamorphic minerals found in IF (Fig. 3). It has long been recognized that in Neoarchean-early Paleoproterozoic IF-bearing basins with a well-preserved shallow- to deep-water depositional profile, deep-water Fe-oxide facies grade into shallow-water Fe-carbonate facies ${ }^{28}$. We suggest that during periods of high $\mathrm{Fe}(\mathrm{II})$ upwelling, the deep-water, photic zone (that also contained low $\mathrm{O}_{2}$ concentrations due to the activity of cyanobacteria) was populated with Gallionella-type cells above the chemocline and Chlorobium-type cells below the chemocline, but throughout the active $\mathrm{Fe}(\mathrm{II})$ oxidation zone, cell densities were on average $10^{5}$ cells per $\mathrm{ml}$ or less. As Gallionella, in particular, forms $\mathrm{Fe}(\mathrm{III})$ with a $\mathrm{C}: \mathrm{Fe}$ ratio of $1: 6$, but the reduction of $\mathrm{Fe}$ (III) in sediments with dead biomass has a C:Fe ratio 1:4, then excess $\mathrm{Fe}$ (III) is accumulated, leading to haematite and magnetite formation with small amount of disseminated siderite found in most deep-water IF, such as the Dales Gorge Member (Fig. 3). This also applies for photoferrotrophic bacteria, as shown by Posth et al. ${ }^{43}$, due to only partial deposition of the biomass while all precipitated $\mathrm{Fe}$ (III) minerals sediment to the ocean floor.

By contrast, in the shallow-water environments, where only a limited amount of upwelling $\mathrm{Fe}$ (II) was supplied, the relative numbers of photoferrotrophs/Gallionella were lower (because their electron donor $\mathrm{Fe}^{2+}$ is limiting under such conditions), whereas higher riverine nutrient input could have resulted in cyanobacterial blooms. This would have led to the production of ferric iron (via the indirect reaction of $\mathrm{O}_{2}$ with ferrous iron) at a $\mathrm{C}$ :Fe ratio of 1:4 (or even greater). This is equivalent to, or even greater, than the reduction ratio, thereby minimizing the amount of $\mathrm{Fe}$ (III) buried. Importantly, the cyanobacteria would have produced biomass that was not tied to $\mathrm{Fe}(\mathrm{II})$ oxidation, thereby increasing the overall $\mathrm{C}: \mathrm{Fe}$ ratio in the sediments. Furthermore, given the possibility that significant concentrations of $\mathrm{H}_{2}$ were also present (via fermentation) in the water column ${ }^{50}$, autotrophic photosynthesis decoupled from $\mathrm{Fe}(\mathrm{II})$ oxidation would have also added biomass, causing a rise in the C:Fe ratio. Therefore, massive siderite with precursor spherical siderite would have formed in the transition zone to the shallow-water environments. Such siderites have been described in the ca. $2.7 \mathrm{Ga}$ Helen iron formation, Ontario $^{51}$. Disseminated siderite spheres or, at higher metamorphic grade, rhombohedral to anhedral-subhedral siderite grains, however, would be preserved in deep-water, Archaean Fe-oxide facies IF (Fig. 3c). Consistent with this ecological zonation, stromatolites have been described from massive siderite deposits ${ }^{51}$ (Fig. 3b), whereas disseminated siderite spheres and, more commonly, rhombohedral to anhedral-subhedral siderite grains were found in the Gunflint $^{34-38}$, Riverton ${ }^{41}$ and Dales Gorge Fe-oxide facies IF $^{39,40}$.

Although a biological role for the origin of IF has been suggested in the past ${ }^{24}$, we have, for the first time, provided experimental evidence that organic biomass in association with $\mathrm{Fe}(\mathrm{III})$ mineral precipitates forms spherical siderite structures under diagenetic conditions. This, in turn, can be used to argue for the presence of cellular biomass in association with the primary Fe(III) precipitates in IF, thereby implying that biological activity was indeed involved in IF deposition. Perhaps most intriguingly, the abundance of siderite in IF might also be used to estimate the initial amount of sedimentary organic matter in Precambrian ferruginous marine environments and its predominant style of metabolism. Our study points to diverse microbial communities in the Archaean oceans with the shallowwater environments populated by cyanobacterial communities, whereas photoferrotrophs and microaerophilic chemolithoautotrophs were abundant in the deep-water photic zone.

\section{Methods}

Setup and analysis of gold capsule diagenesis simulation experiments Ferrihydrite (chemically synthesized) and glucose (as proxy for biogenic Fe(III) precipitates and microbial biomass) were weighted, mixed and carefully homogenized before they were filled into $3 \mathrm{~cm}$ long gold capsules, which were cut from a 1-m long gold tube with an outer diameter of $2.5 \mathrm{~mm}$ and a wall thickness of $0.2 \mathrm{~mm}$. The capsules were filled with $100 \mathrm{mg}$ of ferrihydrite and with either 4.23 or $16.9 \mathrm{mg}$ glucose. The lower amount of glucose represents an electron ratio of 0.6 , which is the ratio of the electrons potentially released from the carbon in the glucose divided by the electrons potentially accepted by the Fe(III) in the ferrihydrite. The larger amount of glucose represents an electron ratio of 2.4. After the filling, the capsules were closed mechanically and sealed with an arc welding. Closed capsules were then placed into rapid quench autoclaves for pressure and temperature treatment at $1.2 \mathrm{kbar}$ and $170{ }^{\circ} \mathrm{C}$ for 14 days. To stop the reactions, capsules were dropped from the sample chamber into the water-cooled part of the 
autoclave. After incubation, the capsules were either prepared as thick sections and embedded in epoxy resin for identification of the mineral phase content and the mineral spatial arrangement by reflected light microscopy, or the material inside the capsules was taken out for Mössbauer spectroscopy and XRD to identify the iron mineral phases.

\section{References}

1. Klein, C. Some precambrian banded iron formations (BIFSs) from around the world. Their age, geologic setting, mineralogy, metamorphism, geochemistry, and origin. Am. Mineral. 90, 1473-1499 (2005).

2. Cairns-Smith, A. G. Precambrian Solution photochemistry, inverse segregation, and banded iron formations. Nature 276, 807-808 (1978).

3. Braterman, P. S., Cairns-Smith, A. G. \& Sloper, R. W. Photo-oxidation of hydrated $\mathrm{Fe}^{2}$ - Significance for banded iron formations. Nature 303, 163-164 (1983).

4. Konhauser, K. O. \& Amskold, L. et al. Decoupling photochemical Fe(II) oxidation from shallow-water BIF deposition. Earth Planet. Sci. Lett. 258, 87-100 (2007)

5. Cloud, P. Significance of the Gunflint (Precambrian) flora. Science 148, 27-35 (1965).

6. Holm, $\mathrm{N}$. The ${ }^{13} \mathrm{C} /{ }^{12} \mathrm{C}$ ratios of siderite and organic matter of a modern metalliferous hydrothermal sediment and their implications for banded iron formations. Chem. Geol 77, 41-45 (1989).

7. Hartmann, H. Microbial Mats-Stromatolites (eds Cohen, Y., Castenholz, R. W., Halvorson, H. O. \& Boylen, C. W.) 451-453 (John Wiley and Sons, 1984).

8. Widdel, F. et al. Ferrous Iron oxidation by anoxygenic phototrophic bacteria. Nature 362, 834-836 (1993)

9. Kappler, A., Pasquero, C., Konhauser, K. \& Newman, D. K. Deposition of banded iron formations by anoxygenic phototrophic $\mathrm{Fe}(\mathrm{II})$-oxidizing bacteria. Geology 33, 865-868 (2005).

10. Hegler, F., Posth, N. R., Jiang, J. \& Kappler, A. Physiology of phototrophic iron(II)-oxidizing bacteria-implications for modern and ancient environments. FEMS Microbiol. Ecol. 66, 250-260 (2008).

11. Johnson, C. M., Beard, B. L., Beukes, N. J., Klein, C. \& ÓLeary, J. M. Ancient geochemical cycling in the earth as inferred from Fe isotope studies of banded iron formations from the Transvaal Craton. Contrib. Mineral. Petr 144, 523-547 (2003)

12. Yamaguchi, K. E., Johnson, C. M., Beard, B. L. \& Ohmoto, H. Biogeochemical cycling of iron in the Archean-Paleoproterozoic Earth: constraints from iron isotope variations in sedimentary rocks from the kaapvaal and pilbara cratons. Chem. Geol 218, 135-169 (2005).

13. Rouxel, O. J., Bekker, A. \& Edwards, K. J. Iron isotope constraints on the Archean and Paleoproterozoic ocean redox state. Science 307, 1088-1091 (2005).

14. Dauphas, N. et al. Clues from Fe Isotope Variations on the Origin of Early Archean BIFs from Greenland. Science 306, 2077-2088 (2004).

15. Czaja, A. D. et al. Iron and carbon isotope evidence for ecosystem and environmental diversity in the similar to 2.7 to 2.5 Ga Hamersley Province, Western Australia. Earth Planet. Sci. Lett. 292, 170-180 (2010).

16. Johnson, C. M. \& Beard, B. L. Biogeochemical cycling of iron isotopes. Science 309, 1025-1027 (2005).

17. Heimann, A. et al. $\mathrm{Fe}, \mathrm{C}$, and $\mathrm{O}$ isotope compositions of banded iron formation carbonates demonstrate a major role for dissimilatory iron reduction in $\sim 2.5$ Ga marine environments. Earth Planet. Sci. Lett. 294, 8-18 (2010).

18. Perry, E. C., Tan, F. C. \& Morey, G. B. Geology and stable isotope geochemistry of the Biwabik Iron Formation, Northern Minnesota. Econ. Geol. 68 , 1110-1125 (1973).

19. Kashefi, K. \& Lovley, D. R. Extending the upper temperature limit for life. Science 301, 934 (2003).

20. Gole, M. J. \& Klein, C. Banded iron-formations through much of the Precambrian time. J. Geol. 89, 169-183 (1981).

21. Walker, J. C. G. Suboxic diagenesis in banded iron formations. Nature 309, 340-342 (1984)

22. Craddock, P. R. \& Dauphas, N. Iron and carbon isotope evidence for microbial iron respiration throughout the Archean. Earth Planet. Sci. Lett. 303, 121-132 (2011).

23. Han, T. M. Microstructures of magnetite as guides to its origin in some Precambrian iron formations. Fortschritte der Mineralogie 56, 105-142 (1978).

24. McConchie, D. Western Australia. Precambrian Iron-Formations (eds Appel, P. W. U. \& LaBerge, G. L.) 541-597 (1987).

25. Morris, R. C. Genetic modelling for banded iron-formation of the Hamersley Group, Pilbara Craton, Western Australia. Precambrian Res. 60, 243-286 (1993).

26. Krapež, B., Barley, M. E. \& Pickard, A. L. Hydrothermal and resedimented origins of the precursor sediments to banded iron formation: sedimentological evidence from the early Palaeoproterozoic Brockman Supersequence of Western Australia. Sedimentology 50, 979-1011 (2003).
27. Li, J. L., Konhauser, K. O., Cole, D. R. \& Phelps, T. J. Mineral ecophysiological data provide growing evidence for microbial activity in banded-iron formations. Geology 39, 707-710 (2011).

28. Beukes, N. J., Klein, C., Kaufman, A. J. \& Hayes, J. M. Carbonate petrography, kerogen distribution, and carbon and oxygen isotope variations in an early Proterozoic transition from limestone to iron-formation deposition, Transvaal Supergroup, South Africa. Econ. Geol. 85, 663-690 (1990).

29. Winter, B. L. \& Knauth, L. P. Stable isotope geochemistry of cherts and carbonates from the $2.0 \mathrm{Ga}$ Gunflint Iron Formation: implications for the depositional setting, and the effects of diagenesis and metamorphism. Precambrian Res. 59, 283-313 (1992).

30. Johnson, C. M., Beard, B. L., Klein, C., Beukes, N. J. \& Roden, E. E. Iron isotopes constrain biologic and abiologic processes in banded iron formation genesis. Geochim. Cosmochim. Acta. 72, 151-169 (2008).

31. Miyano, T. \& Beukes, N. J. Phase relations of stilpnomelane, ferriannite, and riebekite in very low-grade metamorphosed iron formations. Geol. Soc. So. Africa Trans 87, 111-124 (1984).

32. Trendall, A. F. The Hamersley Basin. Iron-Formations: Facts and problems (eds Trendall, A. F. \& Morris, R. C.) 69-129 (1983).

33. Kaufman, A. J., Hayes, J. M. \& Klein, C. Primary and diagenetic controls of isotopic compositions of iron-formation carbonates. Geochim. Cosmochim. Acta 54, 3461-3473 (1990).

34. Heaney, P. J. \& Veblen, D. R. An examination of globular dubiomicrofossils in Precambrian banded iron formations using the transmission electron microscope. Precambrian Res. 49, 355-372 (1991).

35. Kazmierczak, J. The eukaryotic nature of Eosphaera-like ferriferous structures from the Precambrian Gunflint Iron Formation, Canada: A comparative study. Precambrian Res. 9, 1-22 (1979).

36. LaBerge, G. L. Possible biological origin of Precambrian iron-formations. Econ. Geol. 68, 1098-1109 (1973).

37. Carrigan, W. J. \& Cameron, E. M. Petrological and stable isotope studies of carbonate and sulfide minerals from the Gunflint Formation, Ontario: evidence for the origin of early Proterozoic iron-formation. Precambrian Res. 52, 347-380 (1991).

38. LaBerge, G. L. Microfossils and Precambrian Iron-Formations. Geol. Soc. Am. Bull 78, 331-342 (1967).

39. Trendall, A. F. \& Blockley, J. G. The iron formations of the Precambrian Hamersley Group, Western Australia; with special reference to the associated crocidolite. W. Austr. Geol. Surv. Bull 119 p 336 (1970).

40. Ayres, D. E. Genesis of iron-bearing minerals in banded iron formation mesobands in the dales gorge member, hamersley group, Western Australia. Econ. Geol. 67, 1214-1233 (1972).

41. James, H. L. Iron formation and associated rocks in the Iron River district, Michigan. Geol. Soc. Am. Bull. 62, 251-266 (1951).

42. LaBerge, G. L., Robbins, E. I. \& Han, T. M. A Model for the Biological Precipitation of Precambrian Iron-Formations, A: Geological Evidence, Precambrian Iron-Formations (eds Appel, P. W. U. \& LaBerge, G. L.) 69-96 (1987).

43. Posth, N. R., Huelin, S., Konhauser, K. O. \& Kappler, A. Size, density and composition of cell-mineral aggregates formed during anoxygenic phototrophic $\mathrm{Fe}(\mathrm{II})$ oxidation: Impact on modern and ancient environments. Geochim. Cosmochim. Acta. 74, 3476-3493 (2010).

44. Floran, R. J. \& Papike, J. J. Petrology of the low-grade rocks of the Gunflint Iron-Formation, Ontario-Minnesota. Geol. Soc. Am. Bull. 86, 1169-1190 (1975)

45. Lougheed, M. S. Origin of Precambrian iron-formations in the Lake Superior region. Geol. Soc. Am. Bull. 94, 325-340 (1983).

46. Konhauser, K. O. et al. Did bacteria form Precambrian banded iron formations? Geology 30, 1079-1082 (2002).

47. Konhauser, K. O., Newman, D. K. \& Kappler, A. The potential significance of microbial Fe(III) reduction during deposition of Precambrian banded iron formations. Geobiology 3, 167-177 (2005).

48. Emerson, D. \& Revsbech, N. P. Investigation of an iron-oxidizing microbial mat community located near Aarhus, Denmark - field studies. Appl. Environ. Microbiol. 60, 4022-4031 (1994).

49. Planavsky, N. et al. Iron-oxidizing microbial ecosystems thrived in late Paleoproterozoic redox-stratified oceans. Earth Planet. Sci. Lett. 286, 230-242 (2009).

50. Croal, L. R., Jiao, Y., Kappler, A. \& Newman, D. K. Phototrophic Fe(II) oxidation in the presence of $\mathrm{H}_{2}$ : implications for Banded Iron Formations. Geobiology 7, 21-24 (2009).

51. Hofmann, H. J., Sage, R. P. \& Berdusco, E. N. Archean stromatolites in michipicoten group siderite ore at Wawa, Ontario. Econ. Geol. 86, 1023-1030 (1991).

\section{Acknowledgements}

We thank M Nowak, D Russ and I Gill-Kopp for support with sample preparation and pressure/temperature experiments. U Neumann is acknowledged for advice on reflected light microscopy. This work was funded by research grants KA 1736/4-1 and 12-1 from the German Research Foundation (DFG) to A.K., the Promotionsstipendium im 
Promotionsverbund 'Einblicke in die Bakterien-Material-Wechselwirkungen' to I.K., and the Natural Sciences and Engineering Research Council of Canada (NSERC) to Kurt Konhauser and Andrey Bekker. Furthermore, I.K. would like to thank E Swanner, N Posth and M Eickhoff for helpful advice and discussions. D.P. acknowledges support from NASA (grant numbers NNA04CC09A, NNX08AO16G, NNA09DA81A, and NNX12AG14G), Boston College, and the Carnegie Institution of Washington. We thank the drill core facility of the GSWA for providing access and assistance to samples.

\section{Author contributions}

Experiments and analyses were conducted by I.K. A.K. and K.K. designed and developed the project. All authors contributed to the data analysis and writing of the manuscript.

\section{Additional Information}

Supplementary Information accompanies this paper at http://www.nature.com/ naturecommunications

Competing financial interests: The authors declare no competing financial interests.

Reprints and permission information is available online at http://npg.nature.com/ reprintsandpermissions/

How to cite this article: Köhler, I. et al. Biological carbon precursor to diagenetic siderite with spherical structures in iron formations. Nat. Commun. 4:1741 doi: 10.1038/ ncomms2770 (2013). 